\title{
Determining appropriate strategies for improving women's health promoting behaviours: using the nominal group technique
}

\author{
A. Baheiraei, ${ }^{1,2}$ M. Mirghafourvand, ${ }^{3}$ E. Mohammadi, ${ }^{4}$ S. Mohammad-Alizadeh Charandabi ${ }^{3}$ and S. Nedjat ${ }^{5}$
}

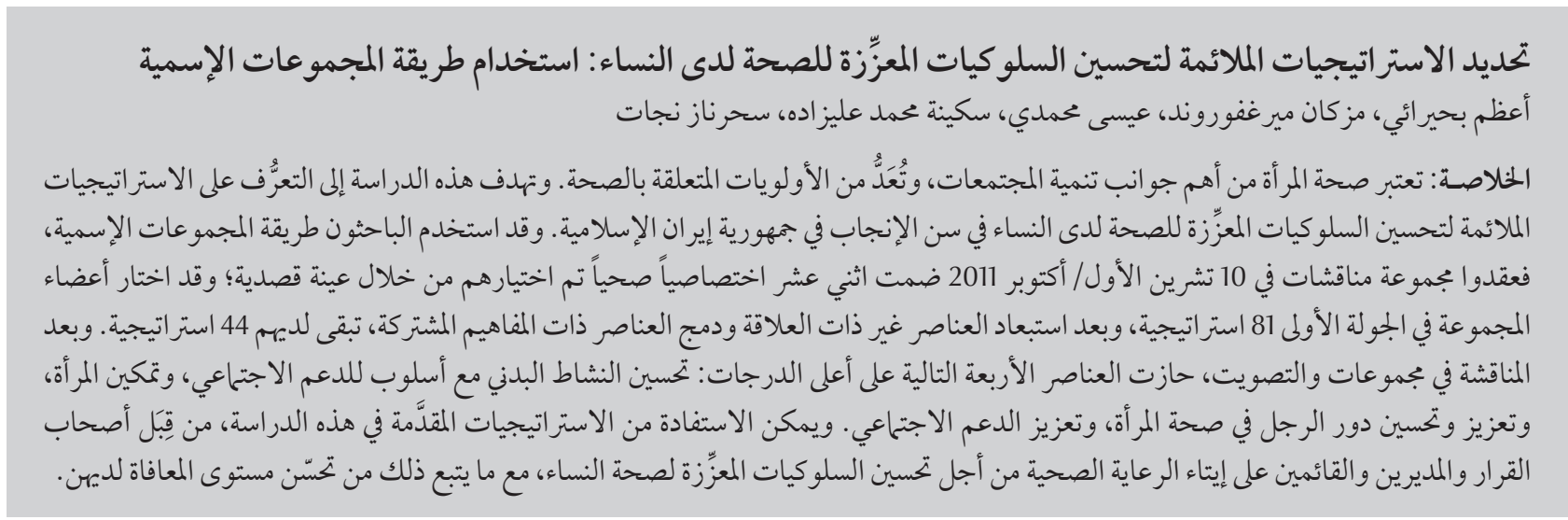

ABSTRACT Women's health constitutes a major aspect of development in societies and is considered a health-related priority. The aim of the present study was to determine appropriate strategies for improving health promoting behaviours in women of reproductive age in the Islamic Republic of Iran. Using the nominal group technique, a panel discussion was held in October 2011 with 12 health specialists who were selected through purposive sampling. In the first round, panel members generated 81 strategies; after eliminating irrelevant items and merging items with similar concepts, 44 strategies remained. After group discussion and voting, the following 4 items had the highest scores: improving physical activity, with a social support approach; empowering women; promoting and improving men's role in women's health; and promoting social support. The strategies presented in this study may be utilized by policy-makers, managers and health care providers to improve women's health promoting behaviours, and thus contribute to their wellbeing.

Détermination des stratégies appropriées visant à renforcer les comportements bénéfiques pour la santé de la femme par la technique du groupe nominal

RÉSUMÉ La santé de la femme qui est un aspect majeur du développement des sociétés, est considérée comme une priorité sanitaire. La présente étude visait à définir les stratégies appropriées pour renforcer les comportements bénéfiques pour la santé des femmes en âge de procréer en République islamique d'Iran. À l'aide de la technique du groupe nominal, un débat a été organisé en octobre 2011 entre 12 spécialistes de la santé sélectionnés selon un échantillonnage dirigé. Au cours de la première rencontre, les membres du groupe ont compilé 81 stratégies ; après l'élimination des éléments non pertinents et le regroupement des éléments couvrant des concepts similaires, 44 stratégies ont été dégagées. Après une discussion et un vote au sein du groupe, les quatre éléments suivants ont obtenu les scores les plus élevés : l'augmentation de l'activité physique, avec une approche apportant un soutien social ; I'autonomisation des femmes ; l'encouragement et l'amélioration du rôle des hommes dans la santé de la femme ; et la promotion du soutien social. Les stratégies présentées dans cette étude peuvent être utilisées par les responsables de l'élaboration des politiques, les gestionnaires et prestataires de soins de santé afin de renforcer les comportements bénéfiques pour la santé des femmes et de contribuer ainsi à leur bien-être.

${ }^{7}$ Department of Reproductive Health; ${ }^{2}$ Centre for Community-Based Participatory Research; ${ }^{5}$ School of Public Health, Knowledge Utilization Research Centre, Tehran University of Medical Sciences, Tehran, Islamic Republic of Iran. ${ }^{3}$ Midwifery Department, Tabriz University of Medical Sciences, Tabriz, Islamic Republic of Iran (Correspondence to M. Mirghafourvand: mirg1385@yahoo.com). ${ }^{4}$ Department of Nursing, Tarbiat Modares University, Tehran, Islamic Republic of Iran.

Received: 17/01/12; accepted: 19/03/12 


\section{Introduction}

Health care services for women often focus on mother and child care and do not pay due attention to women's lifestyles [1]. Women have different health issues than men. In addition to obvious differences related to reproductive health, such as diseases related to pregnancy and birth, certain disorders, such as anaemia, depression, anxiety and eating disorders, are more frequent in women than in men [2]. Risk factors related to diseases such as physical inactivity and obesity are more prevalent among women than men $[3,4]$, so too are mental disorders. In a mental health survey of a population sample aged 15 years and over in the Islamic Republic of Iran, 25.9\% of the women and $14.9 \%$ of the men had mental disorders [5]. In another study, Iranian women reported significantly poorer health-related quality of life compared with men [6]. It has been shown that health promoting behaviours could decrease health problems and improve women's health [3].

Women assume pivotal roles in families and societies and have the potential to encourage positive changes in behaviour and serve as a model for their children and other family members, for example regarding dietary habits, physical activity and personal hygiene $[7,8]$. We can consolidate these healthy behaviours in women through health promotion programmes aimed at women [1]. For developing countries, however, women's health is a more challenging and complicated issue as women have to cope with innumerable obstacles such as discrimination, deprivation of social rights, domestic violence, poverty, hunger and lack of access to medical care, all of which compromise their health [9].

We still lack appropriate strategies to improve women's health in the Islamic Republic of Iran. The rapid changes in fertility status in the country during recent decades have led to a situation in which the majority of Iranian women $(60 \%)$ are of reproductive age [10]. This highlights the need to adopt optimal strategies for improving Iranian women's health promoting behaviours for the benefit of their family and particularly their children. The present study is part of a mixed methods study with a sequential, explanatory design. The protocol of the study has been published previously [11]. The first phase of the study was a quantitative assessment of the status of health promoting behaviours in women of reproductive age. In the second phase, we made a qualitative evaluation of the experiences of women of reproductive age regarding their health promoting behaviours. In the final phase, described here, we used the nominal group technique (NGT) among a group of health specialists with the aim of defining strategies for improving health promoting behaviours in women of reproductive age.

\section{Methods}

\section{Participants}

Health specialists were recruited through purposive sampling. We invited 15 professionals who were experts in women's health issues from different disciplines to participate in the nominal group session. Among these, 12 responded to our invitation. All 12 professionals participating in the nominal group session were experienced in providing health and educational services to women or experts in health issues of women of reproductive age and their background varied from psychology and nursing to sociology and health economics. We selected individuals of different disciplines in order to assess the issue from different aspects and acquire an array of perspectives [12]. Table 1 presents the

\begin{tabular}{lccccc}
\hline \multicolumn{2}{l}{ Table 1 Characteristics of participants in the nominal group panel } & & \\
\hline Participant & Age (years) & Sex & Expertise & Degree & $\begin{array}{c}\text { Duration of experience in the } \\
\text { field of women's health } \\
\text { (years) }\end{array}$ \\
1 & 45 & Female & Health promotion & PhD & 20 \\
2 & 58 & Female & Health promotion & $\mathrm{PhD}$ & 25 \\
3 & 54 & Male & Health promotion & $\mathrm{PhD}$ & 25 \\
4 & 45 & Female & Health promotion & $\mathrm{PhD}$ & 5 \\
5 & 47 & Female & Health promotion & $\mathrm{PhD}$ & 21 \\
6 & 43 & Female & Psychology & $\mathrm{PhD}$ & 19 \\
7 & 42 & Female & Nursing & $\mathrm{PhD}$ & 20 \\
8 & 49 & Male & Nursing & $\mathrm{PhD}$ & 26 \\
9 & 60 & Male & Health economics & $\mathrm{PhD}$ & 33 \\
10 & 38 & Female & Social medicine & $\mathrm{PhD}$ & 4 \\
11 & 45 & Male & Epidemiology & $\mathrm{PhD}$ & 13 \\
\hline
\end{tabular}


participants' characteristics, including age, sex, field of expertise, degree and length of experience in the field of women health.

\section{Data collection}

The NGT session was held on 24 October 2011. Prior to the session, each participant received a briefcase containing a letter that elucidated the objectives of the present study and a summary of the preceding quantitative and qualitative phases of the study as well as the strategies obtained through a review of the literature.

The nominal group session was held in a room with a $U$-shaped table in the Faculty of Nursing and Midwifery of Tehran University of Medical Sciences. A facilitator and a secretary with experience in nominal group sessions helped conduct the NGT session. The facilitator (M.M.) had a PhD in reproductive health and the secretary, a $\mathrm{PhD}$ student of reproductive health, was invited to help implement this session.

\section{Steps of the NGT}

\section{Step 1: Opening the session}

Initially, all the participants were acknowledged for agreeing to take part in the session and the stages of the session were explained to them. We presented the objective of the session as "What are the most appropriate strategies for improving health promoting behaviours in women?", using the findings of previous studies, the current data and the participants' experiences.

\section{Step 2: Silent generation of ideas in writing}

All participants were asked to use the previously presented findings and data, as well as their own experiences, to write down their ideas over a 10minute period. This stage was completed in silence and the participants did not share or discuss their ideas with one another.
Step 3: Round-robin recording of ideas

Subsequently, the secretary wrote the ideas presented by the participants on a flip-chart to be visible by other group members. The ideas belonging to each participant were written, followed by ideas from the next participants, and so on, until all the ideas were equally presented to all members. The ideas were numbered sequentially.

\section{Step 4: Serial discussion on the ideas}

The collected ideas were then discussed and elucidated. For this purpose, the facilitator started the discussion from the top of the list on the flip-chart. Any previously written idea would be eliminated and ideas with similar concepts were merged. In addition, if any ideas were ambiguous, the owner of the idea or other experts in the session would clarify its meaning. This procedure continued until no ambiguity was left about any of the ideas.

\section{Step 5: Voting to select the most im- portant ideas}

Afterwards, the participants were required to select 5 of the most important ideas from the list and write the numbers on an index card. The most important idea would be scored 5; the second most important would be scored 4 , and so on, for 5 ideas selected by each participant. Once this task was completed, the index cards were collected and the score of each idea was written next to it on the flip-chart.

\section{Step 6: Discussion of the selected ideas}

This step, although not indispensable for NGT, is recommended as it helps the group to organize the findings more effectively. Thus, the strategies were classified as personal or structural, according to the experts' opinions.

\section{Validity of the NGT}

We took the following measures to increase the validity of the method: we recruited participants of different disciplines to broaden the range of responses and opinions on the subject in question. Furthermore, we observed the principles for founding and managing the nominal group sessions.

\section{Ethics}

This study was supported by the ethics committee of Tehran University of Medical Sciences. All participants were informed about the objectives of the study, and they all agreed to participate voluntarily. In order to compensate for a small part of the participants' time and energy, they were awarded with presents as souvenirs.

\section{Results}

Individual writing ofideas in silence generated 81 strategies; once the repeated and irrelevant items were eliminated and items with similar concepts were merged, 44 strategies remained. These strategies and their assigned weights are depicted in Table 2. Among these, the following 4 strategies had the highest scores: improving physical activity, with a social support approach; empowering women; promoting and improving men's role in women's health; and promoting social support. These 4 strategies are described in Table 3.

\section{Discussion}

This is the first Iranian study to use the NGT to extract the opinions and ideas of health professionals regarding strategies for improving health promoting behaviours. There are a number of group-oriented research methods to determine individuals' attitudes or perceptions about specific issues [13]. The NGT promotes group decision-making about a specific subject and integrates quantitative and qualitative methodology, as decisions are made through both discussion and voting [14]. NGT has certain advantages over other group 
Table 2 The 44 ideas for strategies for improving health promoting behaviours among women in the Islamic Republic of Iran as generated in the nominal group

\begin{tabular}{|c|c|c|c|}
\hline Strategy & Weighting ${ }^{\mathrm{a}}$ & Total $^{\mathrm{a}}$ & Category \\
\hline $\begin{array}{l}\text { Promoting and improving men's positive impact on enhancement of } \\
\text { women's health: } \\
\text { - educating men about health promoting behaviours, particularly } \\
\text { promoting social support for women in public places; } \\
\text { - encouraging men (via media, mosques and workplaces) to } \\
\text { concern themselves with their wives' health }\end{array}$ & $2,2,3,3,3,4$ & 17 & $\begin{array}{l}\text { Personal } \\
\text { Structural }\end{array}$ \\
\hline $\begin{array}{l}\text { Using advertisements and programmes to educate about the } \\
\text { importance of healthy lifestyles, particularly physical activity } \\
\text { (via media, billboards, short message service and pamphlets) in } \\
\text { collaboration with the health care system and municipalities }\end{array}$ & - & - & Structura \\
\hline $\begin{array}{l}\text { Empowering women: } \\
\text { - establishing programmes (via public media) to introduce healthy } \\
\text { lifestyles to families; } \\
\text { - using positive and negative role models for improving perceived } \\
\text { threats and perceived benefits; } \\
\text { - targeting children and adolescents for improving their problem- } \\
\text { solving skills }\end{array}$ & $5,5,5,4,4,3$ & 26 & $\begin{array}{l}\text { Personal } \\
\text { Structural }\end{array}$ \\
\hline $\begin{array}{l}\text { Planning for low-cost exercises such as family marches (in public) on a } \\
\text { weekly and monthly basis }\end{array}$ & - & - & $\begin{array}{l}\text { Personal } \\
\text { Structura }\end{array}$ \\
\hline $\begin{array}{l}\text { Establishing and developing women's health consulting services and } \\
\text { health education based on health promoting behaviours in cities } \\
\text { by deputies of health, welfare and on different levels of services, } \\
\text { particularly PHC }\end{array}$ & 4 & 4 & Structura \\
\hline $\begin{array}{l}\text { Starting public screening programmes, eg for hypertension, BMI, } \\
\text { cancer and heart diseases }\end{array}$ & - & - & Structura \\
\hline $\begin{array}{l}\text { Improving physical activity, with social support approach: } \\
\text { - legislation (free tickets and sports venues and access hours), } \\
\text { - environment and sports venues; } \\
\text { - facilities (financial, human resources, equipment); } \\
\text { - positive attitude (women, men and legislators); } \\
\text { - outpatient service centres (health care, therapy, rehabilitation) for } \\
\text { treating women's physical problems }\end{array}$ & $5,5,5,5,4,4,3$ & 31 & $\begin{array}{l}\text { Personal } \\
\text { Structural }\end{array}$ \\
\hline Starting traditional and healthy cooking programmes in food festivals & - & - & Structura \\
\hline $\begin{array}{l}\text { Starting time management educational programmes for families in } \\
\text { workplaces, cultural centres of municipalities and media }\end{array}$ & $3,2,1$ & 6 & Structura \\
\hline $\begin{array}{l}\text { Implementing programmes for introducing low-cost methods of stress } \\
\text { management for the public }\end{array}$ & - & - & Structura \\
\hline $\begin{array}{l}\text { Developing stress control consulting centres for employees in } \\
\text { organizations and institutes }\end{array}$ & - & - & Structura \\
\hline Starting screening programmes for work-related stress in organizations & - & - & $\begin{array}{l}\text { Personal } \\
\text { Structural }\end{array}$ \\
\hline $\begin{array}{l}\text { Educating (via organizations and public media) about maintaining } \\
\text { privacy and self-time for women }\end{array}$ & - & - & $\begin{array}{l}\text { Personal } \\
\text { Structura }\end{array}$ \\
\hline $\begin{array}{l}\text { Starting regular exercise programmes and facilities in organizations } \\
\text { and workplaces and making them public on a weekly basis, with } \\
\text { participation of organization managers in order to promote active } \\
\text { lifestyles }\end{array}$ & 2,1 & 3 & Structural \\
\hline $\begin{array}{l}\text { Acknowledging women with healthy lifestyles on networks } \\
\text { in organizations and announcing their strategies to others for } \\
\text { encouraging them to improve their health }\end{array}$ & - & - & Personal \\
\hline Developing legal facilities in working conditions & 2 & 2 & Structura \\
\hline $\begin{array}{l}\text { Providing facilities for health promoting behaviour education in } \\
\text { workplaces }\end{array}$ & - & - & Structura \\
\hline $\begin{array}{l}\text { Providing an equitable legal system for women (with guarantee of } \\
\text { performance) in recognizing fertility rights }\end{array}$ & 3,4 & 7 & Structura \\
\hline
\end{tabular}


Table 2 The 44 ideas for strategies for improving health promoting behaviours among women in the Islamic Republic of Iran as generated in the nominal group (continued)

\begin{tabular}{|c|c|c|c|}
\hline Strategy & Weighting ${ }^{\mathrm{a}}$ & Total $^{\mathrm{a}}$ & Category \\
\hline $\begin{array}{l}\text { Correcting common beliefs regarding women's exercise (via public } \\
\text { media) }\end{array}$ & 1 & 1 & $\begin{array}{l}\text { Personal } \\
\text { Structural }\end{array}$ \\
\hline $\begin{array}{l}\text { Educating about stress control methods and skills (unofficially on } \\
\text { media and officially via classes in clubs and cultural centres) }\end{array}$ & 2,4 & 6 & Structural \\
\hline $\begin{array}{l}\text { Developing and reinforcing women's self-confidence for accepting } \\
\text { health promoting behaviours (via creation of women's clubs) }\end{array}$ & 2,1 & 3 & $\begin{array}{l}\text { Personal } \\
\text { Structural }\end{array}$ \\
\hline $\begin{array}{l}\text { Developing bonds with social systems (eg religious communities), to } \\
\text { collaborate on issues such as mental health and diet }\end{array}$ & 3 & 3 & Structural \\
\hline $\begin{array}{l}\text { Enhancing participation of women in different levels of decision- } \\
\text { making, designing and implementing health improvement } \\
\text { programmes, particularly through encouraging women to volunteer } \\
\text { for health projects (health care team } \rightarrow \text { educating women } \rightarrow \text { helping } \\
\text { other women) }\end{array}$ & 4,1 & 5 & $\begin{array}{l}\text { Personal } \\
\text { Structural }\end{array}$ \\
\hline Encouraging local women's co-operatives & 4 & 4 & Structural \\
\hline Devising a modern model for women's spirituality & - & - & $\begin{array}{l}\text { Personal } \\
\text { Structural }\end{array}$ \\
\hline Monitoring screening programmes based on female risk factors & 2 & 2 & Structural \\
\hline Designing municipal structures for safe women's activities and leisure & - & - & Structural \\
\hline $\begin{array}{l}\text { Improving awareness and attitudes for women, family members and } \\
\text { the whole society about health promoting behaviours (different types) } \\
\text { and their impact on individual and family health through media, } \\
\text { mosques, conventions (seminars, movies) and women's religious } \\
\text { gatherings (female preachers) }\end{array}$ & $1,3,3$ & 7 & $\begin{array}{l}\text { Personal } \\
\text { Structural }\end{array}$ \\
\hline $\begin{array}{l}\text { Facilitating social support on the family level: } \\
\text { - assigning time to women to participate in activities or reducing their } \\
\text { responsibilities by other family members; } \\
\text { - financial support for these activities }\end{array}$ & 4,4 & 8 & Personal \\
\hline $\begin{array}{l}\text { Promoting social support: } \\
\text { - promoting healthy behaviours in local facilities, eg mosques, parks, } \\
\text { sport centres and schools; } \\
\text { - supporting health promoting behaviours in workplaces; } \\
\text { - providing nurseries and daycare centres for child care }\end{array}$ & $5,5,3,2$ & 15 & Structural \\
\hline $\begin{array}{l}\text { Promoting support at higher levels (legal, infrastructures, financial } \\
\text { resources) }\end{array}$ & 3,3 & 6 & Structural \\
\hline $\begin{array}{l}\text { Assessing the impact of health promoting behaviours and providing } \\
\text { feedback accordingly }\end{array}$ & - & - & Personal \\
\hline $\begin{array}{l}\text { Developing short and long-term programmes for women's health via } \\
\text { policies, laws and budgets }\end{array}$ & - & - & Structural \\
\hline $\begin{array}{l}\text { Encouraging cultural education for wives, mothers, daughters and } \\
\text { fathers }\end{array}$ & 5,1 & 6 & $\begin{array}{l}\text { Personal } \\
\text { Structural }\end{array}$ \\
\hline Educating women about self-preservation and responsibility skills & - & - & Personal \\
\hline $\begin{array}{l}\text { Enhancing self-esteem, self-efficiency, strong will and making personal } \\
\text { choices among women }\end{array}$ & - & - & Personal \\
\hline $\begin{array}{l}\text { Providing environmental and social facilitators, eg public welfare, } \\
\text { social support, policies fighting discrimination and sexism, survival } \\
\text { conditions, municipal environment and neighbourhood relations }\end{array}$ & $5,2,1$ & 8 & Structural \\
\hline $\begin{array}{l}\text { Forming female-oriented civil organizations particularly on the local } \\
\text { scale }\end{array}$ & 4,4 & 8 & Structural \\
\hline Defining women's share in decision-making positions and occupations & 5 & 5 & Structural \\
\hline Forming women's social identity and role in society & 3 & 3 & Structural \\
\hline $\begin{array}{l}\text { Improving social capital through encouraging the feeling of belonging } \\
\text { to a neighbourhood, city, country and society }\end{array}$ & - & - & Structural \\
\hline
\end{tabular}




\begin{tabular}{|c|c|c|c|}
\hline Strategy & Weighting ${ }^{\mathrm{a}}$ & Total $^{\mathrm{a}}$ & Category \\
\hline $\begin{array}{l}\text { Reinforcing the skills for improving mental health and providing the } \\
\text { equipment for improving these skills }\end{array}$ & 2,2 & 4 & Personal \\
\hline $\begin{array}{l}\text { Investing in public sports instead of competitive sports with an } \\
\text { emphasis on women's sports }\end{array}$ & 1 & 1 & Structural \\
\hline $\begin{array}{l}\text { Modelling women's success in improving family and neighbourhood } \\
\text { health }\end{array}$ & - & - & Personal \\
\hline
\end{tabular}

${ }^{a}$ Empty weighting and sum columns for a strategy indicate that the idea was not selected by any of the participants to be among the top 5 priorities. $P H C=$ primary health care $B M I=$ body mass index .

techniques, such as the Delphi method, focus groups and brainstorming, which render it one of the most efficient group procedures. One advantage is completion of the process in one session with immediate submission of results to the group, which improves the participants' satisfaction. Moreover, researcher bias is minimized as a result of the highly structured nature of the process [15]. Although the NGT is one of the best methods to adopt efficient decisions about one subject, it has not been paid due attention in Iranian health care system and its benefits and efficiency remain to be evaluated.

Improving physical activity, with a social support approach, was the highest scoring strategy in the session. Women's inactivity is a challenge not only for women in the Islamic Republic of Iran, but also in many other countries [16-18]. Considering the important role of physical activity in preventing coronary artery disease, type 2 diabetes and colon cancer, as well as improving mental health, reducing the risk of obesity and osteoporosis [19], this strategy may be beneficial to women's health. Social support is typically classified as perceived and received support and it includes 3 main aspects: emotional (e.g. feeling loved, valued and appreciated), informational (e.g. advice or guidance) and instrumental (e.g. tangible help) [20]. According to our experts, this strategy could be realized on the structural level in the Islamic Republic of Iran through instrumental support, such as enhancing sport facilities and spaces, human resources, increasing the active hours of sport centres, providing free tickets and spaces and providing outpatient service (health care, therapy, rehabilitation) for treating women's physical problems. On the personal level, it may be actualized through informational support such as promoting positive attitudes in women, men and legislators towards women's physical activity.

Empoweringwomen was the second highest scoring strategy presented in the specialist panel. Empowerment is an important aspect of health improvement, and is defined as: "enabling individuals to decide about their own health". Since this strategy focuses on empowering individuals as well as society as a whole, it is practical and efficient for comprehensive health promotion [21].

The third highest scoring strategy in the nominal group session was promoting and improving men's role in women's health. This may be accomplished through educating health promoting behaviours, particularly promoting social support for women and encouraging men to concern themselves with their wives' health as propagated in media, mosques and workplaces. Men play a pivotal role in women's health through their encouragement of behaviour modification and reduction of reproductive health problems as well as the problems of domestic violence that women encounter. The United Nations Population Fund has stated that as men play an essential role in empowering women [22]. Thus, any comprehensive approach to women's health requires a component for improving men's participation [2].

Promoting social support ranked fourth among the suggested strategies. Numerous studies have indicated the positive impact of social support on health promoting behaviours $[16,17]$. In fact, social support is necessary for health promotion, as it satisfies individuals' physical and emotional needs and protects quality of life against stressful events [23]. As our experts agreed, this strategy may be realized through promoting health behaviours in local facilities such as mosques, parks, sport centres, and schools, support health promoting behaviours in workplaces, and providing nurseries and day-care centres to take care of children. The characteristics of a community and its organizations have a direct effect on the level of well-being on the individuals and families that reside in it. Promoting close-knit ties among residents can relieve the effects of crises on community members. Stable communities are characterized by value similarity, mutual assistance, shared trust and concern for members [24].

This study has some limitations that are worth mentioning. First, similar to other qualitative methods, the NGT is limited in sample size. Secondly, participants were selected purposively, and therefore, the representativeness and generalizability of the results are limited. Thirdly, the generation of ideas was limited to the actual time spent at the meeting. 


\begin{tabular}{|c|c|c|c|}
\hline Strategy & $\begin{array}{l}\text { Absolute } \\
\text { weighting }\end{array}$ & \% weighting & Category \\
\hline $\begin{array}{l}\text { Improving physical activity with social support approach: } \\
\text { - legislation (free tickets and sports venues and access hours) } \\
\text { - environment and sports venues } \\
\text { - facilities (financial human resources equipment) } \\
\text { - positive attitude (women men and legislators) } \\
\text { - outpatient service centres (health care therapy rehabilitation) for treating } \\
\text { women's physical problems }\end{array}$ & 31 & 34.8 & $\begin{array}{l}\text { Personal } \\
\text { Structural }\end{array}$ \\
\hline $\begin{array}{l}\text { Empowering women: } \\
\text { - establishing programmes (via public media) to introduce healthy lifestyles to } \\
\text { families } \\
\text { - using positive and negative role models for improving perceived threats and } \\
\text { perceived benefits } \\
\text { - targeting children and adolescents for improving their problem-solving skills }\end{array}$ & 26 & 29.2 & $\begin{array}{l}\text { Personal } \\
\text { Structural }\end{array}$ \\
\hline $\begin{array}{l}\text { Promoting and improving men's positive impact on enhancement of women's health: } \\
\text { - educating men about health promoting behaviours, particularly promoting } \\
\text { social support for women in public places } \\
\text { - encouraging men (via media, mosques and workplaces) to concern themselves } \\
\text { with their wives' health }\end{array}$ & 17 & 19.1 & $\begin{array}{l}\text { Personal } \\
\text { Structural }\end{array}$ \\
\hline $\begin{array}{l}\text { Promoting social support: } \\
\text { - promoting healthy behaviours in local facilities, e.g. mosques, parks, sport } \\
\text { centres and schools } \\
\text { - supporting health promoting behaviours in workplaces } \\
\text { - providing nurseries and daycare centres for child care }\end{array}$ & 15 & 16.9 & Structural \\
\hline Total & 89 & 100.0 & \\
\hline
\end{tabular}

\section{Conclusion}

This study using NGT provided useful information regarding strategies for improving health promoting behaviours. Among the strategies discussed, improving physical activity with social support, empowering women, promoting and improving men's role in women's health and promoting social support had the highest scores respectively. The strategies presented in this study may be utilized by policy-makers, planners, managers, researchers and health care providers to improve women's health promoting behaviours, and thus contribute to their well-being.

\section{Acknowledgements}

We wish to express our gratitude to all experts who participated in the nominal group session.

Funding: This work was supported by the Tehran University of Medical Sciences (project number 89-02-28-10802).

Competing interests: None declared.

\section{References}

1. Esin NM, Bulduk S. Healthy behaviours and educational needs among Turkish women: a school-based study. Collegium Antropologicum, 2008, 32:1043-1051.

2. Strategic action for the health of women in Europe. Copenhagen, World Health Organization Regional Office for Europe, 2001.

3. Amin-Shokravi F, Rajabi R, Ziaee N. Exercise effects on risk of cardiovascular disease among Iranian women. Asian Journal of Sports Medicine, 2011, 2:37-43.

4. Bakhshi E et al. Changes in body mass index across age groups in Iranian women: results from the national health survey. Journal of Nutrition and Metabolism, 2012, doi: 10.1155/2012/848403

5. Noorbala AA et al. Mental health survey of the adult population in Iran. British Journal of Psychiatry, 2004, 184:70-73.

6. Tajvar M, Arab M, Montazeri A. Determinants of health-related quality of life in elderly in Tehran, Iran. BMC Public Health, 2008, 8:323.
7. Ribeiro PS et al. Priorities for women's health from the Global Burden of Disease study. International Journal of Gynaecology and Obstetrics, 2008, 102:82-90.

8. Chamberlain J et al. Women's perception of self-worth and access to health care. International Journal of Gynaecology and Obstetrics, 2007, 98:75-79.

9. Luthra R. Internet health learning to improve women's health. World Health Organization. Bulletin of the World Health Organization, 2005, 83:557.

10. National Census of Population and Housing of Iran. Statistical Center of Iran (http://amar.sci.org.ir, accessed 29 January 2013) [in Farsi].

11. Baheiraei A et al. Health-promoting Behaviours and social support of women of reproductive age, and strategies for advancing their health: protocol for a mixed methods study. BMC Public Health, 2011, 11:191. 
12. Abdullah MMB, Islam R. Nominal Group Technique and its Applications in Managing Quality in Higher Education. Pakistan Journal of Commerce and Social Sciences, 2011, 5:81-99.

13. Williams PL et al. Clinical education and training: using the nominal group technique in research with radiographers to identify factors affecting quality and capacity. Radiography, 2006, 12:215-224.

14. Nelson JS et al. Using the nominal group technique for homework communication decisions. remedial and special education. Remedial and Special Education, 2002, 23:380.

15. Potter M, Gordon S, Hamer P. The nominal group technique: a useful consensus methodology in physiotherapy research. Newe Zealand Journal of Physiotherapy, 2004, 32:126-130.

16. Adams MH et al. Social support and health promotion lifestyles of rural women. Online Journal of Rural Nursing and Health Care, 2000, 1:28-40.

17. Chen $\mathrm{CM}$ et al. Postpartum Taiwanese women: their postpartum depression, social support and health-promoting life style profiles. Journal of Clinical Nursing, 2007, 16:1550-1560.

18. Al-Kandari F, Vidal VL. Correlation of the health-promoting lifestyle, enrollment level, and academic performance of col- lege of nursing students in Kuwait. Nursing and Health Sciences, 2007, 9:112-119.

19. Sparling PB et al. Promoting physical activity: the new imperative for public health. Health Education Research, 2000, 15:367-376.

20. Toronton PL et al. Weight, diet and physical activity-related beliefs and practices among pregnant and postpartum Lationo women: the role of social support. Maternal and Child Health Journal, 2006, 10:95-104.

21. Kermode $\mathrm{K}$ et al. Empowerment of women and mental health promotion: a qualitative study in rural Maharashtra, India. BMC Public Health, 2007, 7:225.

22. Sternberg P, Hubley J. Evaluating men's involvement as a strategy in sexual and reproductive health promotion. Health Promotion International, 2004, 19:389-396.

23. Bomar PJ. Promoting health in families-applying family research and theory to nursing practice. Philadelphia, WB Saunders, 2004.

24. Pender NJ, Murdaugh CL, Parson M. Health promotion in nursing practice. Philadelphia, New Jersey, 2001.

\section{EZ-DOC tool for health promotion and education}

The WHO Regional Office for the Eastern Mediterranean has developed a documentation tool for health promotion and education called EZ-DOC. EZ-DOC is a user-friendly tool to assist health promotion and education managers document their interventions during the processes of planning and reporting. The tool was developed following requests from Member States of the Region at the Ninth Global Conference on Health Promotion.

The tool is divided in two parts.

- Part 1: Planning and implementation

- Part 2: Documentation and reporting.

Part 1 should be used at the beginning of project development and includes sections on: project information; prioritization of health issue; target beneficiaries; operational planning. Part 2 should be used when the project is completed to highlight lessons learnt.

While the tool was developed to document health promotion and education interventions, it can also be used to document interventions in various sectors.

Further information about this tool can be found at: http:/ /www.emro.who.int/health-education/hed-news/ez-doc. html 